\title{
IDENTIFIKASI GOLONGAN SENYAWA DAN \\ UJI TOKSISITAS AKUT EKSTRAK ETANOL 95 \% DAUN, KULIT BATANG DAN \\ AKAR PULAI (Alstonia scholaris (L.) R. Br.) TERHADAP MENCIT BALB/C
}

\author{
Fadhilatul Ismiyah, Begum Fauziyah, Roihatul Muti’ag, A.Ghanaim Fasya
}

Jurusan Kimia, Fakultas Sains dan Teknologi, UIN Maulana Malik Ibrahim Malang

\begin{abstract}
Use of traditional medicine derived from the active ingredient over a variety of plants chosen by the publicin treating some kinds of diseases. One of the herbs that have been used by people as a medicine is plant Pulai (Alstonia scholaris (L.) Br.). This study was conducted to support the potential Pulai as medicine by providing information that Pulai plants safe to eat. The purpose of this study was to determine the compound and the $\mathrm{LD}_{50}$ value of $95 \%$ ethanol extract of the leaves, bark and roots of Pulai. The study was conducted with a sample extract leaves, bark and roots Pulai with 95\% ethanol. Extracts were obtained using test phytochemical and identification using Thin Layer Chromatography. After that acute toxicity tests on mice BALB/C. Results of phyto chemical test, 95\% ethanol extract of leaves of Pulai give positive results alkaloid sand saponins; $95 \%$ ethanol extract of the stem bark Pulai gives positive results in alkaloids, saponins, and terpenoids $95 \%$ ethanol extract ofthe roots ofPulaigives positive results inalkaloidsandterpenoids.LD $\mathrm{D}_{50}$ valueof $95 \%$ ethanolextract of the leaves, bark and roots are $>5.000 \mathrm{mg} / \mathrm{kg}$ bw which indicates that the plant extract Pulai is practically non-toxic and safe for consumption.
\end{abstract}

Keywords:Pulai (Alstonia scholaris (L.) R. Br), identification of compound, toxicity test

\section{ABSTRAK}

Pemakaian obat tradisional yang berasal dari bahan aktif beberapa macam tumbuhan lebih dipilih oleh masyarakat dalam mengobati beberapa macam penyakit. Salah satu tumbuhan yang telah dimanfaatkan oleh masyarakat sebagai obat adalah tumbuhan Pulai (Alstonia scholaris (L.) Br.). Penelitian ini dilakukan untuk mendukung akan potensi Pulai sebagai obat dengan memberikan informasi bahwa tumbuhan Pulai aman dikonsumsi. Tujuan dari penelitian ini adalah untuk mengetahui golongan senyawa dan nilai $\mathrm{LD}_{50}$ dari ekstrak etanol $95 \%$ daun, kulit batang dan akar Pulai. Penelitian ini dilakukan dengan mengekstrak sampel daun, kulit batang dan akar Pulai dengan etanol $95 \%$. Ekstrak yang diperoleh digunakan uji fitokimia dan identifikasi menggunakan Kromatografi Lapis Tipis. Selanjutnya uji toksisitas akut terhadap mencit BALB/C. Hasil dari uji fitokimia ekstrak etanol $95 \%$ daun Pulai memberikan hasil positif alkaloid dan saponin; ekstrak etanol $95 \%$ kulit batang Pulai memberikan hasil positif pada alkaloid, saponin, dan terpenoid ekstrak etanol $95 \%$ akar Pulai memberikan hasil positif pada alkaloid dan terpenoid. Nilai $\mathrm{LD}_{50}$ dari ekstrak etanol $95 \%$ daun, kulit batang dan akar adalah $>5.000 \mathrm{mg} / \mathrm{Kg}$ BB yang menunjukkan bahwa ekstrak tumbuhan Pulai adalah praktis tidak toksik dan aman untuk dikonsumsi.

Kata kunci: Pulai (Alstonia scholaris (L.) Br.), identifikasi golongan, uji toksisitas akut

\section{PENDAHULUAN}

Tumbuhan Pulai (Alstonia scholaris

(L.) R. Br.) merupakan salah satu jenis tumbuhan yang ada di Insonesia. Manfaat yang biasanya diambil dari tumbuhan Pulai diantaranya sebagai obat demam, malaria, limpa membesar, batuk berdahak, diare, disentri, kurang nafsu makan, sakit perut, kencing manis, hipertensi, wasir, anemia, dan rematik akut (Dalimartha, 2001; Khyade, 2008; Zuraida, 2010)..
Kandungan senyawa tumbuhan Pulai diantaranya golongan triterpen, steroid, alkaloid dan saponin (Djumidi et al., 1993; Boaz et al., 1957; Bader, 1953).

Toksisitas akut adalah efek berbahaya yang terjadi segera setelah terpapar dosis tunggal atau berulang dalam waktu 24 jam (Priyanto, 2010).

Baliga et al. (2004) melakukan penelitian mengenai uji toksisitas akut dari ekstrak etanol $85 \%$ kulit batang Pulai dan 
menyebutkan bahwa sampai pada dosis $2.000 \mathrm{mg} / \mathrm{Kg}$ BB tidak menimbulkan kematian terhadap hewan coba. Namun untuk nilai toksisitas akut dari bagian tumbuhan Pulai yang lain seperti daun dan akar masih belum diketahui, sehingga perlu dilakukan penelitian mengenai uji toksisitas akut dari tumbuhan Pulai untuk menilai keamanan penggunaannya sebagai obat bahan alam.

Penelitian ini dilakukan untuk mengetahui senyawa apa saja yang terdapat dalam ekstrak etanol $95 \%$ tumbuhan Pulai. Dan bagaimanakah nilai uji toksisitas akut tumbuhan Pulai.

\section{METODE PENELITIAN}

Alat

Alat-alat yang digunakan dalam penelitian adalah Rotary evaporator, pipet ukur $5 \mathrm{~mL}$, bola hisap, erlenmeyer $500 \mathrm{~mL}$, gelas ukur $100 \mathrm{~mL}$,neraca analitik, gelas arloji, penyaring buchner dan shakker, plat tetes, pipet tetes, plat KLT silika gel 60 $\mathrm{F}_{254}$, pipa kapiler, bejana pengembang dan lampu UV, kandang hewan coba, botol minum, tempat makan mencit, dan sonde.

\section{Bahan}

Bahan-bahan yang digunakan antara lain adalah daun, kulit batang, dan akar Pulai(Alstonia scholaris, (L.) R. Br.), etanol95 \%, larutan CMC (Carboxy Methyl Cellulose) $\mathrm{Na} 0,5 \%$, akuades, $\mathrm{HCl} 1 \%$, reagen dragendorff, reagen mayer, logam $\mathrm{Mg}$, alkohol, $\mathrm{HCl}$, etanol panas, eter, dan pereaksi lieberman burchard, n-hesana, etil asetat, kloroform, metanol, n-butanol, asam asetat, dan amoniak. Hewan coba yang digunakan adalah mencit Balb/C.

\section{Cara Kerja \\ Ekstraksi}

Serbuk dari masing-masing sampel tumbuhan Pulai (daun, kulit batang dan akar) ditimbang sebanyak 100 gr. Dibagi dalam dua erlenmeyer (masing-masing 50 gr)dan dimaserasi dengan $350 \mathrm{~mL}$ etanol 95 $\%$ selama 24 jam. Kemudian disaring dan dipekatkan dengan rotary evaporator.

\section{Uji Fitokimia}

Uji Alkaloid (Saxena et al. et al, 2012)

Sebanyak 0,5 g ekstrak tumbuhan Pulai ditambahkan $5 \mathrm{~mL} \mathrm{HCl} \mathrm{1 \%} \mathrm{kemudian}$ disaring. Filtrat yang diperoleh dibagi menjadi 2 dimasukkan dalam tabung reaksi. Tabung reaksi I ditambahkan $2-3$ tetes reagen Dragendorff, sedangkan tabung reaksi II ditambahkan $2-3$ tetes pereaksi Mayer. Jika pada tabung I terbentuk endapan jingga-coklat dan pada tabung II terbentuk endapan putih atau kekuningkuningan maka ekstrak menunjukkan adanya alkaloid.

\section{Uji Flavonoid (Saxena et al. et al, 2012)}

Shinoda test: masing-masing ekstrak daun, kulit batang dan akar Pulai dimasukan dalam tabung reaksi kemudian ditambahkan alkohol panas $1-2 \mathrm{~mL}$. Selanjutnya ditambahkan logam magnesium $(\mathrm{Mg})$ dan beberapa tetes $\mathrm{HCl}$ pekat. Jika larutan berubah penampilan menjadi merah, jingga atau ungu maka menunjukan adanya flavonoid.

\section{Uji Saponin (Saxena et al. et al, 2012)}

Sebanyak 0,5 g ekstrak daun, kulit batang dan akar Pulai masing-masing dimasukkan ke dalam tabung reaksitertutup, ditambahkan $10 \mathrm{~mL}$ air.Kemudian dikocok selama 10 detik dan dibiarkan selama 15menit. Adanya saponin ditunjukkan dengan terbentuknya busa/buih yang stabil.

\section{Uji Terpenoid dan Steroid (Indrayani, 2006)}

Ekstrak daun, kulit batang dan akar Pulai dimasukkan dalam tabung reaksi, dilarutkan dalam $0,5 \mathrm{~mL}$ kloroform dan ditambahkan dengan asam asetat anhidrat. Campuran ini selanjutnya ditambah dengan $1-2 \mathrm{~mL} \mathrm{H}_{2} \mathrm{SO}_{4}$ pekat melalui dinding tabung tersebut. Jika hasil yang diperoleh berupa cincin kecoklatan atau violet pada perbatasan dua pelarut menunjukkan adanya terpenoid, sedangkan jika terbentuk warna hijau kebiruan menunjukkan adanya steroid. 


\section{Identifikasi golongan dengan KLT}

Identifikasi golongan senyawa dengan KLT dilakukan pada golongan senyawa alkaloid (ekstrak daun, kulit batang dan akar), saponin (ekstrak daun dan kulit batang) dan terpenoid (ekstrak kulit batang dan akar).

Masing-masing ekstrak etanol $95 \%$ daun, kulit batang dan akar Pulai ditotolkan pada plat silika gel $F_{254}$. Setelah kering plat dielusi pada bejana pengembang yang sebelumnya telah dijenuhkan.

Jenis campuran eluen yang digunakan adalah:

1. Golongan senyawa alkaloid: metanolamoniak (200:3) (Suryanti et al., 2005) dan kloroform-etanol (9:1) (Ekasari et al., 2005). Dengan penyemprot Dragendorff.

2. Golongan senyawa saponin: kloroform : metanol : air (64:50:10)(Wonohadi, 2006), dengan penyemprot Lieberman Burchard.

3. Golongan senyawa terpenoid: metanol-kloroform (2:3) (Hasballah et al., 2006) dan n-heksana-etil asetat (1:9) (Ismarti, 2011), dengan penyemprot Lieberman Burchard.

\section{Uji toksisitas akut}

Mencit diadaptasi selama satu minggu. Kemudian disonde pada hari ke- 8 dengan ekstrak etanol $95 \%$ daun, kulit batang dan akar Pulai. Variasi dosis yang diberikan adalah $500 \mathrm{mg} / \mathrm{Kg} \mathrm{BB}, 1.500$ $\mathrm{mg} / \mathrm{Kg}$ BB, $2.500 \mathrm{mg} / \mathrm{Kg} \mathrm{BB}$ dan 3.500 $\mathrm{mg} / \mathrm{Kg}$ BB. Ekstrak dilarutkan dengan CMC-Na 0,5\%.

\section{HASIL DAN PEMBAHASAN Ekstraksi}

Hasil ekstraksi maserasi dari daun, kulit batang dan akar Pulai ditunjukkan pada Tabel 1.

Tabel 1. Rendemen hasil ekstraksi maserasi

\begin{tabular}{|c|c|c|}
\hline No. & Ekstrak etanol 95 \% & $\begin{array}{c}\text { Rendemen }(\%) \\
(\mathbf{b} / \mathbf{b})\end{array}$ \\
\hline 1. & Daun Pulai & 20,5 \\
\hline 2. & Kulit batang Pulai & 11,47 \\
\hline 3. & Akar Pulai & 10,89 \\
\hline
\end{tabular}

\section{Uji Fitokimia}

Hasil uji fitokimia ekstrak etanol 95 $\%$ daun, kulit batang dan akar Pulai ditunjukkan pada Tabel 2 .

Tabel 2. Hasil uji fitokimia

\begin{tabular}{|c|c|c|c|c|}
\hline No. & Metabolit & \multicolumn{3}{|c|}{ Ekstrak etanol 95 \% } \\
\cline { 3 - 5 } & sekunder & Daun & $\begin{array}{c}\text { Kulit } \\
\text { batang }\end{array}$ & Akar \\
\hline 1. & Alkaloid & + & + & + \\
2. & Flavonoid & - & - & - \\
3. & Saponin & + & + & - \\
4. & Terpenoid & - & + & + \\
5. & Steroid & - & - & - \\
& & & & \\
\hline
\end{tabular}

\section{Identifikasi dengan KLT}

Identifikasi senyawa alkaloid daun dengan eluen metanol : amoniak (200:3) memberikan pemisahan dengan terbentuknya 6 spot, dan nilai Rf 0,$16 ; 0,48$; 0,$55 ; 0,63 ; 0,68 ; 0,79$. Hasil pemisahan ditunjukkan pada Gambar 1.

Gambar 1. Hasil pemisahan alkaloid daun Pulai

Spot yang diduga sebagai senyawa alkaloid adalah pada $\operatorname{Rf} 0,16$ dan 0,79. Menurut Harborne (1996) timbulnya bercak coklat jingga setelah disemprot dengan pereaksi Dragendorff menunjukkan adanya senyawa alkaloid.

Identifikasi senyawa alkaloid kulit batang dengan eluen metanol : amoniak (200:3) menghasilkan 3 spot. Nilai Rf dari spot yang terbentuk adalah 0,$14 ; 0,85$; dan 0,89 . Ketiga spot yang terbentuk diduga adalah senyawa alkaloid. Hasil pemisahan ditunjukkan pada Gambar 2. 


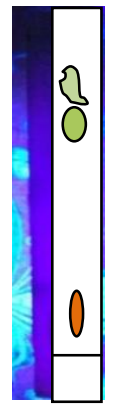

Gambar 2. Hasil pemisahan alkaloid kulit batang

Pemisahan alkaloid dengan akar Pulai dengan kloroform : etanol (9:1) menghasilkan 8 spot dengan $\operatorname{Rf} 0,16 ; 0,26$; 0,$36 ; 0,42 ; 0,47 ; 0,58 ; 0,68 ; 0,74$. Spot yang diduga sebagai alkaloid adalah pada spot 0,$16 ; 0,36 ; 0,47$; dan 0,58 . Hasil pemisahan ditunjukkan pada Gambar 3.

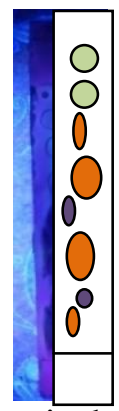

Gambar 3. Pemisahan alkaloid akar Pulai

Pemisahan senyawa saponin daun menggunakan kloroform : aseton (4:1) menghasilkan 11 spot. Dengan nilai Rf 0,$16 ; 0,21 ; 0,33 ; 0,39 ; 0,44 ; 0,50 ; 0,62$; 0,$66 ; 0,77 ; 0,84 ; 0,97$. Yang diduga sebagai senyawa saponin adalah pada spot 0,44. Sedangkan pada pemisahan senyawa saponin kulit batang dengan kloroform : metanol : air (64:50:10) menghasilkan 8 spot, nilai $\mathrm{Rf}$ dari spot yang terbentuk adalah 0,$31 ; 0,53 ; 0,58 ; 0,66 ; 0,71 ; 0,79$; 0,$84 ; 0,89$. Spot yang diduga sebagai senyawa saponin adalah pada spot 0,71 dan 0,79 . Hasil pemisahan ditunjukkan pada Gambar 4.

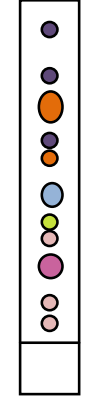

(a)

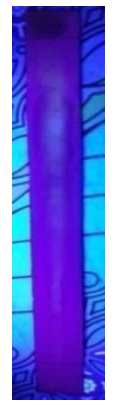

Gambar 4. Pemisahan daun saponin (a) dan kulit batang saponin (b)

Pemisahan senyawa terpenoid kulit batang dengan metanol : kloroform $(2: 3)$ menghasilkan 4 spot dengan $\operatorname{Rf} 0,28 ; 0,38$; 0,$47 ; 0,53 ; 0,87$. Spot yang diduga sebagai senyawa terpenoid ada pada spot 0,28; 0,$38 ; 0,47$; dan 0,53 . Pemisahan senyawa terpenoid akar dengan n-heksana : etil asetat (1:9) memberikan pemisahan dengan terbentuknya 4 spot. Nilai Rf dari masingmasing spot adalah 0,$18 ; 0,22 ; 0,47$; dan 0,95 . Yang diduga sebagai senyawa terpenoid adalah pada spot 0,56. Hasil pemisahan ditunjukkan pada Gambar 5.

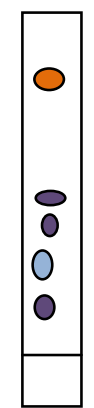

(a)

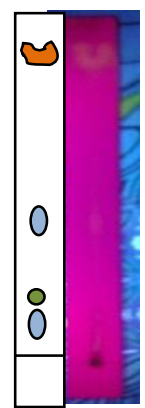

(b)
Gambar 5. Pemisahan terpenoid kulit batang (a) dan akar (b)

Robinson (1995) menyebutkan bahwa warna biru yang muncul diakibatkan oleh adanya reaksi Lieberman-Burchard pada senyawa terpenoid dan steroid, bila sterol dan triterpena alkohol dicampur dengan anhidrat asetat dan setetes asam sulfat pekat maka akan dihasilkan warna biru. Bahri (2005) menyebutkan bahwa senyawa terpenoid dengan pereaksi LiebermanBurchard ditandai dengan 
terbentuknya warna ungu, merah jambu dan ungu kemerahan.

\section{Uji toksisitas akut}

Hasil pengujian toksisitas akut ekstrak etanol daun, kulit batang dan akar Pulai tidak membuat hewan coba mati. Bahkan saat dosis dinaikkan pada dosis $4.500 \mathrm{mg} / \mathrm{Kg}$ BB dan $5.000 \mathrm{mg} / \mathrm{Kg}$ BB tetap tidak menimbulkan kematian terhadap hewan coba. Yang terjadi hanya perubahan tingkah laku dari hewan coba seiring dengan naiknya dosis yang diberikan. Semakin besar dosis yang diberikan membuat hewan coba / mencit lebih banyak diam dan tidak banyak makan. Dari hasil tersebut dapat disimpulkan bahwa nilai $\mathrm{LD}_{50}$ ekstrak etanol daun, kulit batang dan akar Pulai adalah > $5.000 \mathrm{mg} / \mathrm{Kg} \mathrm{BB}$, yang berarti praktis tidak toksik (Loomis, 1978).

\section{KESIMPULAN}

Hasil penelitian menunjukkan bahwa ekstrak etanol $95 \%$ daun terdapat senyawa alkaloid dan saponin. eksrtak etanol $95 \%$ kulit batang terdapat senyawa alkaloid, saponin dan terpenoid. dan ekstrak etanol $95 \%$ akar terdapat senyawa alkaloid dan terpenoid. uji toksisitas akut yang dilakukan menunjukkan bahwa nilai $\mathrm{LD}_{50}$ daun, kulit batang dan akar Pulai adalah lebih dari $5.000 \mathrm{mg} / \mathrm{Kg} \mathrm{BB}$, yang berarti praktis tidak toksik.

\section{DAFTAR PUSTAKA}

Baliga MS, Jagetia GC, Ullor JN, Baliga MP, Venkatesh P, Reddy R, Rao KVN M, Baliga BS, Devi S, Raju SK, Veeresh V, Reddy TK, Bairy KL. 2004. The Evaluation of the Acute Toxicity and Long Term Safety of Hydroalcoholic Extact of Sapthaparna (Alstonia Scholaris) in Mice and Rats.Toxicology Letters. 151: 317-326.

Bader. 1953. Structure of Alstonine. Helv. Chim, Acta 36: 215.
Boaz, et al. 1957. Structure of Alstonidine From the Bark Of Root Of Alstonia Constricta. F. Muell. J. Am. Pharm, Assoc. 46: 508.

Dalimartha S. 2001. Atlas Tumbuhan Obat Indonesia Jilid 1. Jakarta: Trubus Agriwidya.

Djumidi H, Sugiarso S, dan Gotama I. 1997. Inventaris Tumbuhan Obat Indonesia Jilid IV.Jakarta: Departemen Kesehatan Balitbang Kesehatan.

Ekasari, Wiwied., Widyawaruyanti, Aty dan Hafid, Achmad Fuad. 2005. Uji Antimalaria Hasil Fraksinasi Ekstrak Kloroform Daun Siamea pada Mencit Terinfeksi Plasmodium berghei. Laporan Penelitian Tidak Diterbitkan. Surabya: Fakultas Farmasi Universitas Airlangga.

Indrayani L, H. Soetjipto dan L. Sihasale. 2006. Skrining Fitokimia dan Uji Toksisitas Ekstrak Daun Pecut Kuda (Stachytarpheta jamaicensis L. Vahl) Terhadap Larva Udang Artemia salina Leach. Jurnal Fakultas Sains dan Matematika. Salatiga: Universitas Kristen Satya Wacana.

Harborne JB. 1987. Metode Fitokimia Penentuan Cara Modern Menganalisis Tumbuhan. Penerjemah Kosasih Padmawinata dan Iwang Soediro. Bandung: ITB.

Hasballah K, Murniana dan Al-azhar. 2006. Aktivitas Antibakteri dan Antifungi Dari Tumbuhan Wedelia biflora. Jurnal Kedokteran YARSI. 14 (1) : 38-45.

Ismarti. 2011. Isolasi Triterpenoid dan Uji Antioksidan Dari Fraksi Etil Asetat Kulit Batang Meranti Merah (Shorea singkawang (Miq). Miq). Artikel. Andalas: Kimia Pascasarjana Universitas Andalas.

Khyade MS and Vaikos NP.2008. Phytochemical and antibacterial properties of leaves of Alstonia scholaris $\mathrm{R}$. Br. 
Loomis TA. 1978. Toksikologi Dasar. Semarang: IKIP Press.

Priyanto. 2010. Toksikologi. Depok: Leskonfi (Lembaga Studi dan Konsultasi Farmakologi).

Robinson T. 1995. Kandungan Organik Tumbuhan Tingkat Tinggi. Bandung: ITB.

Saxena N, Shrivastava PN dan Saxena RC. 2012. Preliminary PhysicoPhytochemical Study of Stem Bark of Alstonia Scholaris (L.) R. Br. a Medicinal Plant. International Journal of Pharmaceutical Science and Research. India: UPSR.
Suryanti V, Dewi MS, Kristinawati, D. 2005. Komponen Kimia Buah Pare Belut (Trichosanthes anguina L.). Jurnal Alchemy, 4 (2): 28-34.

Wonohadi E, Diah AP, Diana AB, Sri L, Melani. 2006. Identifikasi Senyawa Anti Mikroba Rimpang Temu Giring (Curcuma Heyneana Val dan Van Zijp) secara Bioautografi. Surabaya: Fakultas Farmasi Universitas Surabaya.

Zuraida, Effendi R, Lelana NE. 2010. Prospek Pulai (Alstonia sp) Sebagai Bahan Baku Obat Anti Kolesterol. Bogor: Badan Penelitian dan Pengembangan Kehutanan. 